\title{
The Implementation of PAKEM Using Cooperative Learning Method on Taxation Accounting Subject
}

\author{
Widi Dwi Ernawati*, Erlin Melani, Retno Widiastuti \\ Accounting Department \\ State Polytechnic of Malang \\ Malang, Indonesia \\ *jengwidi@gmail.com, erlinmelani13@gmail.com, retnow_utik@yahoo.com
}

\begin{abstract}
The objective of this research is to implement $P A K E M$ method as an effort to improve the students' understanding and skill on taxation accounting subject. PAKEM is the acronym of Pembelajaran Aktif, Kreatif, Efektif dan Menyenangkan (Active Learning, Creative, Effective, and Fun). The cooperative learning method used is Think Pair Share (TPS), Jigsaw, and Group Investigation (GI). Considering this method can improve the students' participation and soft skill, it is chosen. The research was conducted by using Classroom Action Research(CAR) design. The success of this method is measured with two components: 1) the student's active participation and contribution in group discussions; 2) individual scores on the understanding and analysis capability on taxation accounting subject. The minimum target of the two components is 73 of 100 scale. The result of the treatment to the students of sixth semester by using this method shows that the students' active participation improves and the individual average scores is over 73. Based on the result of the implementation of the method, we can draw two conclusions: 1) It can improve the students' soft skill and competence on taxation accounting subject. 2) The students give a very positive and constructive reflection and responses to this method.
\end{abstract}

Keywords: PAKEM, cooperative learning, accounting taxation

\section{INTRODUCTION}

Taxation accounting is one of the subjects taught in sixth semester in the Management Accounting, State Polytechnic of Malang. Taxation accounting is not like other subjects that have original basic knowledge. It is a hybrid (a mixture between commercial accounting with taxation) and is more applicable than the original knowledge. In industrial world, state-owned companies (BUMN) and private ones tend to hire those who can handle tax and accounting as well (two-in-one) because it is more practical and low cost. That aspect is an advantage to the graduates of The Management Accounting Department, State Polytechnic of Malang compared to those who also study taxation. For example: bachelors on law or bachelors on tax.

Students have to take subjects that are related to accounting and taxation before they take taxation accounting. They have to take Introduction to Accounting I, Introduction to Accounting II, Intermediate Financial Accounting I and II. The subjects related to taxation the students have to take are Taxation and Taxation Practice. If the students cannot achieve good results in the two subjects, it will be hard for them to achieve good results in the Taxation Accounting subject.

The learning method commonly used these days is lecturing. The lecturers become the centre of the teachinglearning process (lecturer-centered learning) as if they were the only sources of the knowledge. This teaching method in which the lecturers are active but the students are passive are certainly not effective. At the time when the students are attending a certain subject with lecturing method, most of them tend to understand the subjects or make notes only. Some of them are even sleepy. The result of teaching-learning process by using lecturing method so far does not give a satisfactory result.To achive the expected result, it is important to implement the suitable method in delivering the Taxation Accounting subject.

Government's Regulation Number 20, Year 2003 about Educational National System states that learning is an interaction process of the students with the lecturers and the learning source in a learning environment. A concept as mentioned in that regulation brings a consequence that a learning activity should be focused on the students' activity so that the the institution will know how far the teaching-learning objectives that have been schedulled are achieved. Referring to the regulation, it is clearly understood that learning process, no matter wherever it takes place, should be done actively, innovatively, creatively, through dialogues, open-minded, in an impressive situation and gives a meaning to the students. In this case, PAKEM as one of teaching models that has been developed and promoted massively has a strong relationship to the expected objective juridically and formally.

PAKEM is the acronym of Pembelajaran Aktif, Kreatif, Efektif dan Menyenangkan (Active Learning, Creative, Effective, and Fun). PAKEM starts from a concept that a learning should be focused on the students and learning should be fun to make the students motivated to keep learning independently without feeling depressed or feeling feared [1] Being active means the lecturer should create such a situation so that the students are active to ask questions, to express their ideas, and search for the required data to solve their problems. Being creative may also mean creating various learning activities to develop the students' potensial. Effective means generating the expected objective as the product of a learning activity. Fun means creating an interesting learning situation so that the students can focus their concentration on the 


\section{RESUlTS, ANALYSIS, AND DISCUSSION}

In its implementation, a learning method should be in line with the students' needs because each learning method has different objectives, principles, and focuses. There are several various models that can be implemented in a cooperative learning: Student Team Achievement Division (STAD); Jigsaw; Group Investigation (GI); Rotating Trio Exchage; and Group Resume. Other statements state that a cooperative learning can be done through experiement, group discussions, problem solving, information searching, report writing/poem writing/ essay writing. It can be done through industrial visit, too. This study uses Think Pair Share (TPS), Jigsaw, and Group Investigation (GI).

Based on the research design, there are four steps used in conducting this research (Planning, Acting, Monitoring, and Reflection):

\section{A. Planning Steps}

There are two activities in this step. The first step is Creating developed learning scenarios based on the PAKEM concepts by using cooperative learning method. The scenario designed is to determine the learning strategy according to the following teaching materials.

TABLE I. TOPICS AND LEARNING STRATEGY completion of the tasks in group as well [5]. Almost all research on cooperative learning shows similar results, such as other research [6-8]. Based on the explanations in the previous lines, the researcher is interested in The Implementation of PAKEM through Cooperative Learning Method to improve the students' competence in Taxation Accounting.. The purpose of this research is to know the impact of implementing PAKEM to Taxation Account subject through Cooperative Learning Method.

\section{MethodS}

The research was conducted by using Classroom Action Research design (CAR). The design used in this study follows the Kemmis, S \& Taggart, R. Model [9]. A Classroom Action Research is defined as a dynamic process in which there are four aspects: planning, acting, observing/monitoring and reflecting.

This research was conducted in sixth semester, academic year 2018/2019 in The Accounting Department, State Polytechnic of Malang. The object of the research is the students of The Management Accounting Study Programme who were taking are studying Taxation Accounting subject.

This research used qualitative and quantitative data. Qualitative data were obtained when the researcher performed the observation step during the learning process recorded in the observation sheet. Quantitative data were obtained from the students' written test scores. The final scores were converted into the following criteria (The Academic Guidebook of State Polytechnic of Malang): $\mathrm{N} \leq 39$ (failed);39 $<\mathrm{N}<50$ (less), 50 $<\mathrm{N} \leq 60$ (fair), $60<\mathrm{N} \leq 65$ better than fair), $65<\mathrm{N} \leq 73$ (good), $73<\mathrm{N} \leq 80$ (better than good), $80<\mathrm{N} \leq 100$ (very good).

\begin{tabular}{|c|c|}
\hline TOPICS & $\begin{array}{c}\text { The Learning } \\
\text { Strategy }\end{array}$ \\
\hline $\begin{array}{l}\text { ASIC PRINCIPLES OF TAX ACCOUNTING: } \\
\text { Relation to tax accounting and commercial } \\
\text { ccounting } \\
\text { Basic concept of taxation accounting } \\
\text { Accounting accounts for taxation }\end{array}$ & $\begin{array}{l}\text { Think Pair } \\
\text { Share }\end{array}$ \\
\hline $\begin{array}{l}\text { OOKKEEPING: } \\
\text { Accounting obligations } \\
\text { Recording } \\
\text {. Letter of Tax Return }\end{array}$ & $\begin{array}{l}\text { Think Pair } \\
\text { Share }\end{array}$ \\
\hline $\begin{array}{l}\text { CCOUNTS ON FINANCIAL POSITION } \\
\text { TATEMENTS RELATED TO TAXES: } \\
\text { Cash and Bank Accounting } \\
\text { Accounting receivables } \\
\text {. Inventory Accounting } \\
\text { Short term and long term investment } \\
\text { ccounting } \\
\text { The accounting of tangible and intangible fixed } \\
\text { ssets } \\
\text { Debt accounting } \\
\text { Stock capital Accounting and equity }\end{array}$ & Jigsaw \\
\hline $\begin{array}{l}\text { NCOME TAX ACCOUNTING: } \\
\text { A. Income } \\
\text { Expenses } \\
\text { Fiscal reconciliation/Taxable income } \\
\text { alculation } \\
\text { Loss Compensation } \\
\text { Current tax }\end{array}$ & Jigsaw \\
\hline $\begin{array}{l}\text { EFERRED TAX ACCOUNTING } \\
\text { Temporary differences } \\
\text { Difference a temporary taxable tax } \\
\text { Reduced temporary differences } \\
\text { Calculation of deferred tax assets (DTA) } \\
\text { Calculation of deferred tax liabilities (DTL) } \\
\text { Deferred income Tax } \\
\text { I. Deferred Income expense } \\
\text { I. Presentation of financial statements }\end{array}$ & Jigsaw \\
\hline
\end{tabular}


The jigsaw learning strategy consists of several members Table I. Cont.

\begin{tabular}{|c|c|c|}
\hline 6. & $\begin{array}{l}\text { ADDED VALUE ON TAX ACCOUNTING } \\
\text { AND Vat BM: } \\
\text { A. Tax Invoices } \\
\text { B. Tax input and tax output } \\
\text { C. Crediting of input tax on next tax period } \\
\text { D. Excess VAT }\end{array}$ & Jigsaw \\
\hline 7. & $\begin{array}{l}\text { ACCOUNTING FOR CERTAIN BUSINESS } \\
\text { TAX: } \\
\text { A. Leasing accounting } \\
\text { B. Accounting for construction services } \\
\text { C. E-Commerce Accounting } \\
\text { D. Accounting for Muharabah }\end{array}$ & Jigsaw \\
\hline 8. & $\begin{array}{l}\text { TAX PLANNING of EMPLOYEES TAX } \\
\text { INCOME: } \\
\text { A. Selection of cost Natura \& enjoyment } \\
\text { B. The selection of PPh borne and allowances PPh } \\
\text { C. Setting of employee insurance premiums } \\
\text { D. Selection of net, gross, gross up }\end{array}$ & $\begin{array}{l}\text { Group } \\
\text { Investigation }\end{array}$ \\
\hline 9. & $\begin{array}{l}\text { TAX PLANNING OF COMPANY TAX } \\
\text { INCOME } \\
\text { A. Selection of depreciation methods } \\
\text { B. Cost savings through revaluation of fixed } \\
\text { assets } \\
\text { C. Cost savings through Leasing } \\
\text { D. Supply method Selection } \\
\text { E. Interest Expense utilization } \\
\text { F. Selection of Business Forms } \\
\text { G. Business Activity Selection } \\
\text { H. Selection of capital placement }\end{array}$ & $\begin{array}{l}\text { Group } \\
\text { Investigation }\end{array}$ \\
\hline
\end{tabular}

The second activity in planning step is forming groups. The lecturer must have data about the students' intelligence level, before forming groups. The data can be obtained from lists of Grade Point Average (GPA) in the previous semester. Each group has members with composition: high, medium and low ability.

\section{B. Acting Step}

The lecturer provides information to students, saying that the teaching-learning will use cooperative learning method by using the following strategy : Group Investigation, Jigsaw and Think Pair Share. The lecturer can use Group Investigation (GI) strategy to teach the students communication skill and good grouping process. The followings are the six steps that have to be done in this model: a) Choosing the Topics. The students choose certain sub-topics on a general issue. That issue is commonly chosen by the lecturer; b)Cooperative Planning. The lecturer assisted by the students plan the learning procedures and its specific objectives related to the chosen subtopic; c) Implementing. The students implement the plan that has been designed in the second step. The lecturer records the groups' progress and offers an assistance if needed; d)Analysing and Sinthesizing. The students analyze and evaluate the information they get in the third step and plan how to summarize and prepare the presentation in front of an audience; e)Presenting the final result. Some groups or all groups have to present the research findings, the objective of which is to let all members of the groups understand the topic. This activity is co-ordinated by the lecturer; f)Evaluating. When some groups discuss different aspects of the same topic, the students and the lecturer will evaluate every group's contribution for the classroom's need. The evaluation can be done individualy or in groups. in one group who are responsible for the mastery of some parts of the materials and they should be able to deliver them to the members of their own groups. The steps of a Jigsaw model are as follows : a) The students are grouped into 4 to 5 members; b) Each member of the team gets a different part c) Each member of the team gets the chosen part; d) Different members of different teams who have learned the same chapters/subchapters meet in a new group (group of experts) to discuss their sub-chapters; e) Each member of the expert group returns to their own group and teaches the members one by one about the sub-chapter they have mastered. The members have to memorize the materials carefully; f) Each expert then should present the result of the discussion; g) The lecturer evaluates the presentation; h) Closing.

The Jigsaw strategy has the following characteristics: a) Each member of the group studies a different part of information that is also different from the other's of other groups; b) Each member should work together to have a complete understanding on the given topic; c) Each member of all groups should share their information with other members from other groups to have complete information; d) There should be an expert in each group; e) After all the members share their information with their own groups, they give questions based on the whole material; f) The lecturer assesses the students' works, evaluate their individual progress, and records the group progress. Further step is to give a reward to the group with the highest progress.

In this strategy, the lecturer gives a different assignment on a certain topic to the groups. Each member of each group becomes an expert on the topic their get. The next step is the experts of the groups who get the same topic establish a new group based on the topic they get. In this step, the experts who gather in the new group try to solve the given problem. After they get the solution of the problem, they return to their previous groups and teach the solution to the members. The members then compile the information delivered by the experts with their own.

Think-Pair-Share strategy (TPS) has a certain structure that has been designed explisitly to let the students have more time to think, answer, and assist each other. The designed steps are as follows: a) Thinking. The lecturer asks the students a question or an issue related to the topic and tells them to think about it for a few minutes independently; b) Pairing. The lecturer tells the students to get different pairs to discuss what they have though at the thinking step. Usually, a lecturer will give 4 to 5 minutes to each pair; c) Sharing, as the last step. The lecturer tells the pair students to share what they have discussed with their class mates. This will be effectively done pair by pair till a quater of the students in the classroom get their turns to present their reports.

To implement this strategy, the planned activities are as follows: a) The lecturer delivers the main material and the expected competence; b) The students are expected to think about the materials/ the case delivered by the lecturer; c) The students are grouped into pairs to say their own ideas; d) The lecturer chairs the small discussions. Each pair says the result of their discussions; e) Started from that activity, the lecturer 
At the last meeting of learning process, the lecturer gives

leads the topic to the main case and delivers additional material that has not been delivered; f) The lecturer draws the conclusions; g) Closing.

\section{Monitoring (Observation) Step}

There are two activities in this step. The first step is documentation. Monitoring is conducted by the lecturer $\mathrm{him} /$ herself while the implementation of learning is done by recording the events in the observation sheet. Based on the observations on the implementation of the step, the students were really interested in learning activities with cooperative learning methods. This could be seen from the students' activities in participating in the learning activities and in group assignment activities. The students actively asked, shared ideas in the discussion and answered the lecturer's questions and they looked happy. The results of the observations and the recording will be used by the lecturer as an input to improve the course material or for further evaluation.

The second activity is assessment. Assessment consists of the processed scores and the scores of learning outcomes that consist of: a) Group scores or joint scores is the achievement of groups in learning. The scores are measured through the student's active participation and contribution in group discussions; b) An individual score is the score that will differ individual's performance in a group. The scores are related to the understanding and analysis capability on taxation accounting subject; c) The final score is the combination of the average of individual scores with the group score. The minimum target of the two components is 73 of 100 scale. At the next meeting for the group that gets the highest number of scores will get reward. This reward made students happy and motivated to achieve the best value. The result of the treatment to the students of sixth semester by using this method shows that the students' active participation improves and the individual average scores is over 73 .

\section{Reflection Step}

The objective of this research is to implement PAKEM method as an effort to improve the students' understanding and skill on taxation accounting subject. The cooperative learning method used is Group Investigation, Think Pair Share (TPS) and Jigsaw. Considering this method can improve the students' participation and soft skill, it is chosen. The success of this method is measured with two components: 1) the student's active participation and contribution in group discussions 2) individual scores on the understanding and analysis capability on taxation accounting subject.

The result of this study shows that cooperative learning method can improve the students' competence in taxation accounting subject. These results support the previous research related to cooperative learning method. Cooperative learning is widely recognised as a pedagogical practice that promotes socialization and learning among students from pre-school through to tertiary level and across different subject domains. It involves students to work together to achieve common goals or complete group tasks - goals and tasks that they will be unable to complete by themselves [10]. questionnaires to obtain respons related to the cooperative learning method. Based on the questionnaires given to the students, it is found that the students give a very positive and constructive reflection and responses to this method. This results also support the previous research by Alabekee that stated it enables learners to receive positive feedback from the process of thinking, enhances students' academic achievement better than the traditional instruction and promotes group interactive learning experience [11]. Cooperative learning is used to serve various ability students taking into consideration of their level of understanding, learning styles, sociological backgrounds that develop students' academic achievement and skills, and breeze the social harmony among students of different ethnic backgrounds [12]. It is therefore recommended that lecturers should use cooperative learning in their regular classroom lessons. Cooperative learning is one of the most widespread and fruitful areas of theory, research, and practice in education. The consistency of the results and the diversity of the cooperative learning methods provide strong validation for its effectiveness [13].

\section{CONCLUSIONS}

The result of the treatment to the students of sixth semester by using this method shows that the students' active participation improves and the individual average scores is over 73. Based on the result of the implementation of the method, researcher can draw two conclusions: 1) PAKEM can improve the students' soft skill and competence on taxation accounting subject. 2) The students give a very positive and constructive reflection and responses to this method.

\section{REFERENCES}

[1] D. Budimansyah, PAKEM Pembelajaran Aktif, Kreatif, Efektif, dan Menyenangkan. Bandung: PT Genesindo, 2009.

[2] Isjoni, Cooperative Learning Efektifitas Pembelajaran Kelompok Bandung: Alfabeta, 2011.

[3] L. Baloche and C.M. Brody, "Cooperative learning: exploring challenges, crafting innovations," Journal of Education for Teaching, vol. 43, no. 3, pp. 274-283, 2017.

[4] F. Bolukbas, F. Keskin and M. Pollat, "The Effectiveness of Cooperative Learning on The Reading Comprehension Skills in Turkish as a Foreign Language", The Turkish Online Journal of Educational Technology, vol. 10 , no. 4 , pp. $330-335,2011$

[5] Chamisah, "An Analysis on The Advantages of Cooperative Learning Approach In Teaching Writing", Englisia, vol. 10, no. 1, pp. 136-154, 2013

[6] T.M. Yemi, Nurulwahida Binti Hj Azid, Madya Ruzlan bin Md Ali, "Cooperative Learning : An Approach for Teaching Mathematics In Public School", European Journal of Social Sciences Studies", vol. 2, no. 10, pp. 122-132, 2018

[7] V.D. Tran, "The Effects of Cooperative Learning on the Academic Achievement and Knowledge Retention", International Journal of Higher Education, vol. 3, no. 2, pp. 131-140, 2014

[8] S.Y. Chu, "Application of the Jigsaw Cooperative Learning Method in Economics Course," International Journal of Managerial Studies and Research (IJMSR), vol. 2, no. 10, pp. 166-172, 2014.

[9] S. Kemmis and R. Taggart, The Action Research Planner, 3rd ed., Reprinted. Victoria: Deakin University, 1990. 
[12] Md.A. Hossain, R.A. Tarmizi and A.F.M. Ayub, "Collaborative and Cooperative Learning in Malaysian Mathematics Education", IndoMS J.M.E, vol. 3, no. 2, pp. 103-114, 2012.

[10] R. Gillies, "Cooperative Learning: Review of Research and Practice", Australian Journal of Lecturer Education, vol. 41, no. 3, pp. 39-54, 2016

[11] E. Alabekee, A. Samuel, S.D. Osaat, "Effect of Cooperative Learning Strategy on Students Learning Experience and Achievements in Mathematics", International Journal of Education Learning and Development, vol. 3, no. 4, pp. 67-75, 2015.

[13] D.W. Johnson, R.T. Johnson and M.B. Stanne, Cooperative Learning Methods: A Meta-Analysis. University of Minnesota, 2000. 